\title{
Oregano essential oil in the diet of broilers: performance, carcass characteristics, and blood parameters
}

\author{
G. Eler $^{1 \#}$, A.V.C. Gomes ${ }^{2}$, B.S. Trindade ${ }^{3}$, L.S.L. Almeida ${ }^{3}$, F. Dilelis ${ }^{2}$, V.S. Cardoso ${ }^{4}$ \& C.A.R. \\ Lima $^{2}$ \\ ${ }^{1}$ Foundation Institute for Fisheries of Rio de Janeiro State (FIPERJ). Rio de Janeiro, Brazil \\ ${ }^{2}$ Department of Nutrition and Pasture, Federal Rural University of Rio de Janeiro. Seropédica, Brazil \\ ${ }^{3}$ Zootechinist, Master of Animal Science for Federal Rural University of Rio de Janeiro. Seropédica, Brazil \\ ${ }^{4}$ Institute of Microbiology Paulo de Góes, Federal University of Rio de Janeiro. Rio de Janeiro, Brazil
}

(Received 6 July 2019; Accepted 17 August 2019; First published online 17 September 2019)

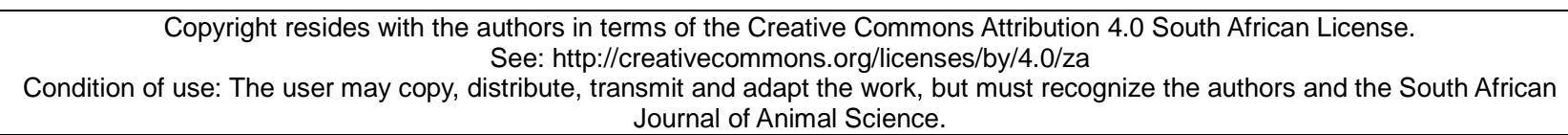

\begin{abstract}
Efficacy of the phytogenic feed additive oregano essential oil (OEO) (Origanum vulgare L.) was assessed as an alternative to an antibiotic as a growth promoter (AGP) in broiler diets. Three hundred male broiler chicks were assigned to five treatments, which consisted of diets with different levels of OEO (300, 600 , and $900 \mathrm{mg} / \mathrm{kg}$ of diet), a negative control, and a positive control. Broiler performance was evaluated from 1 to 21 and 1 to 39 days old. From 1 to 39 days old, the broilers of the negative control group presented lower feed intake than those fed OEO300. No significant effect was observed on weight gain. The greatest feed conversion ratio occurred in the positive control group. Broilers treated with OEO300 had greater carcass yield than those in the positive control group. The haemogram, leukogram, and heterophil/lymphocyte ratio were positively influenced by OEO300. Red blood cell and leukocyte counts increased in a dose-dependent manner in broilers fed OEO-supplemented diets, while broilers in the positive control group had the lowest levels of haematocrit, mean corpuscular haemoglobin concentration, and plasma protein. Differential leukometry revealed lymphocyte numbers were increased with OEO treatment and reduced in the positive control group. For hepatic and renal metabolism, the broilers in the positive control group exhibited the greatest serum activities of aspartate aminotransferase, alanine aminotransferase, gamma-glutamyl transferase, and alkaline phosphatase. Although more studies on its efficacy are needed, OEO at $300 \mathrm{mg} / \mathrm{kg}$ may be used as a phytogenic additive in broiler diets, especially those without AGP.
\end{abstract}

Keywords: antibiotic as growth promoter, immune system, phytogenic feed additive.

\# Corresponding author: giselleeler@gmail.com

\section{Introduction}

The production of secondary compounds that are essential for plant survival and preservation depends on genetic and environmental factors. Many of these compounds elicit different reactions in living organisms and are therefore called active principles. Consequently, these plants are characterized as being medicinal, since they exhibit therapeutic activities owing to the presence of one or more active principles (Martins et al., 2003). These plants can be added to animal diets as phytogenic feed additives after being dried and milled or as essential oils (Jacela et al., 2010; Madhupriya et al., 2018). The use of alternative compounds that act as zootechnical additives, ensuring productive efficiency, has received significant attention, especially after the publication by the European Union of Regulation 1831/2003, which, as of January 2006, restricted the use of all antibiotic and chemotherapeutic agents as performance enhancers in animal production.

The main components of oregano essential oil (OEO) (Origanum vulgare L.) are carvacrol and thymol, which together represent up to $85 \%$ of its composition (Burt, 2004). Oregano essential oil has been associated with antifungal (Bedoya-Serna et al., 2018), antibacterial, and antioxidant activity in vitro (Gandra et al., 2013) and in vivo (Zanini et al., 2013; Ri et al., 2017), stimulation of enzyme secretion (He et al., 2017), and modulation of microbial colonization of the gastrointestinal tract and intestinal morphology (Dias 
et al., 2015; He et al., 2017). However, reports of its effects on the performance and carcass characteristics of broilers have been inconsistent, with positive effects on these characteristics (Mathlouthi et al., 2012; Peng et al., 2016) as opposed to no effects (Alp et al., 2012; Koyama et al., 2014) being detected.

Phytogenic feed additives may have beneficial effects on the immunomodulatory activity and antiinflammatory potential of broilers (Mohiti-Asli \& Guanaatparast-Rashti, 2017). Therefore, analyses of blood parameters such as the erythrogram, leukogram, and serum biochemistry are important tools to evaluate the health status and detect pathophysiological phenomena and abnormalities of poultry.

Thus, the objective of this work was to evaluate the effects of OEO on the performance, carcass characteristics, and blood parameters of broilers.

\section{Materials and Methods}

All animal procedures were approved by the Board of Ethics and Animal Experimentation of the Federal Rural University of Rio de Janeiro (Protocol no. 010285).

Three hundred one-day-old male Cobb 500 chicks were used. They were stratified by bodyweight $(43.69 \mathrm{~g})$ and housed in metal battery cages with three levels. Each level was divided into two blocks, and each cage $(0.90 \mathrm{~m}$ long $\times 0.85 \mathrm{~m}$ wide $\times 0.40 \mathrm{~m}$ high) housed 10 broilers. Each cage was provided with a cup-type infant drinking fountain and a plate-type feeder, which were changed to drinkers and feeders at 15 days old.

The chicks had been vaccinated against Marek's disease, fowlpox, Gumboro, and Newcastle disease at the hatchery. Feed rations and water were provided ad libitum throughout the experimental period.

In the first week, the broilers were maintained under constant lighting. In the second week, lighting was provided for 23 hours, while from days 18 to 28 lighting was provided for 16 hours. From 28 days old onwards, the broilers were maintained under natural lighting.

The diets (Table 1) that were provided to the broilers were isoproteic and isocaloric with a starter diet being provided from day 1 to 21 and a grower diet being fed thereafter (days 22 to 39). Both diets were formulated to meet the nutritional requirements of the poultry, according to the recommendations of the Brazilian Poultry and Swine Table (Rostagno et al., 2005). The additives that constituted the treatments were included in the reference diet instead of inert kaolin material.

The treatments consisted of the reference diet (RD) without antimicrobials (negative control); RD with $10 \mathrm{mg}$ colistin/kg feed (positive control); RD with $300 \mathrm{mg} \mathrm{OEO} / \mathrm{kg}$ feed (OEO300); RD with $600 \mathrm{mg}$ OEO/kg feed (OEO600); and RD with $900 \mathrm{mg}$ OEO/kg feed (OEO900).

The OEO was microencapsulated (Givaudan do Brasil Ltd, SP, Brazil), which involves introducing the oil in an organic matrix to preserve it until it is ingested because of the volatile properties of essential oils. The analytical composition of the oil was $67 \%$ carvacrol, $12 \% \rho$-cymene, $6 \%$-terpinene, $5 \%$ thymol, $3.4 \%$ $\beta$-caryophyllene, 2\% linalool, 2\% myrcene, and 1\% a-pinene (Givaudan do Brasil Ltd, São Paulo, Brazil).

To stimulate a microbiological challenge in the broilers, two breeding experiments were carried out before the experiment was initiated, without a sanitary rest and in a box with wood shavings. The broilers that were bred in this bed received no antimicrobials. After natural drying, a sample of this bed was sent to the Laboratory of Microbiology of the Veterinary Institute of UFRRJ for analysis. The total bacterial count was $45 \times 10^{5} \mathrm{CFU} / \mathrm{g}$, using the PCA (plate count agar) method. The total coliform count was $22 \times 10^{4} \mathrm{CFU} / \mathrm{g}$ using the MacConkey method. Salmonella-Shigella agar (ASS) analysis was also performed and the presence of Citrobacter freundii was detected. The bed was sieved and $4 \mathrm{~g} /($ bird.day) were mixed in the feed at $10,12,14,16,18$, and 20 days old.

The performance parameters evaluated were feed intake, weight gain, viability, and feed conversion in the periods from 1 to 21 days old and 1 to 39 days old. The productive efficiency index (PEI) was calculated using the following formula:

$$
\text { PEI }=\frac{\text { bodyweight }(\mathrm{kg}) \mathrm{x} \text { viability }}{\text { age in days } \mathrm{x} \text { feed conversion }} \times 100
$$

At 39 days old, the broilers were fasted for 12 hours immediately prior to euthanasia, which occurred at day 40. To evaluate carcass characteristics, two broilers that were close to the average weight of the group were removed from each replicate, totalling 12 broilers per treatment.

The broilers were euthanized by cervical dislocation, with posterior bleeding in the jugular vein, scalded, plucked, and eviscerated. Subsequently, the carcasses were weighed and stored in plastic bags, which were sealed, labelled, and refrigerated at $4{ }^{\circ} \mathrm{C}$ for 24 hours. After cooling, the carcasses and their cuts were weighed. 
Carcass yield was calculated based on the chilled carcass weight (gutted and without heads and feet) and live weight after fasting. Cut yields were calculated based on the weight of the chilled cuts and chilled carcass.

Table 1 Dietary ingredients and calculated nutrient composition of basal starter and grower diets to which oregano essential oil or the antibiotic colistin sulfate were added (\%, as-fed basis)

\begin{tabular}{|c|c|c|}
\hline Ingredient (\%) & $\begin{array}{c}\text { Starter } \\
\text { (1 to } 21 \text { days old) } \\
\end{array}$ & $\begin{array}{c}\text { Grower } \\
\text { (22 to } 39 \text { days old) }\end{array}$ \\
\hline Maize & 56,189 & 58,997 \\
\hline Soybean meal & 36,140 & 32,567 \\
\hline Soybean oil & 3,020 & 3,993 \\
\hline Dicalcium phosphate & 1,834 & 1,695 \\
\hline Limestone & 0,880 & 0,837 \\
\hline Salt & 0,492 & 0,471 \\
\hline Inert (kaolin) & 0,800 & 0,800 \\
\hline DL-Methionine & 0,238 & 0,228 \\
\hline L-lysine $\mathrm{HCl}$ & 0,161 & 0,176 \\
\hline Vitamin mix $^{1}$ & 0,100 & 0,100 \\
\hline Mineral mix ${ }^{2}$ & 0,050 & 0,050 \\
\hline L-Threonine & 0,036 & 0,036 \\
\hline Cloreto de colina & 0,050 & 0,040 \\
\hline $\mathrm{BHT}$ & 0,010 & 0,010 \\
\hline \multicolumn{3}{|l|}{ Calculated composition } \\
\hline Crude protein (\%) & 20,7900 & 19,4100 \\
\hline Metabolizable energy (Mcal/kg) & 3,0000 & 3,1000 \\
\hline Calcium (\%) & 0,8840 & 0,8240 \\
\hline Available phosphorus (\%) & 0,4420 & 0,4110 \\
\hline Sodium (\%) & 0,2140 & 0,2050 \\
\hline \multicolumn{3}{|l|}{ Digestible amino acids (\%) } \\
\hline Arginine & 1,3588 & 1,2545 \\
\hline Lysine & 1,1641 & 1,0908 \\
\hline Methionine + Cysteine & 0,8199 & 0,7799 \\
\hline Methionine & 0,5329 & 0,5070 \\
\hline Threonine & 0,7520 & 0,7031 \\
\hline Tryptophan & 0,2361 & 0,2178 \\
\hline
\end{tabular}

${ }^{1}$ Provided per kg of product: vit. A: $7.500 .000 \mathrm{UI}$; vit. $\mathrm{D}_{3}: 2.500 .000 \mathrm{UI}$; vit. E: $18.000 \mathrm{mg}$; vit. $\mathrm{K}_{3}: 1.200 \mathrm{mg} ;$ vit. $\mathrm{B}_{1}: 1.500$ mg; vit. $B_{2}: 5.500 \mathrm{mg}$; vit. $B_{6}: 2.000 \mathrm{mg}$; vit. $B_{12}: 12.500 \mathrm{mcg}$; biotin: $67 \mathrm{mg}$; pantothenic acid: $10 \mathrm{~g}$; niacin: $35 \mathrm{~g}$; ${ }^{2}$ Provided per kg of product: Mn: 120 g; Cu: 13 g; Fe: 60 g; Zn: 100 g; I: 2500 mg; Se: 500 mg

Blood samples from two broilers per experimental unit, totalling 60 broilers, were collected at 40 days old for haematological analysis. Samples for haemogram and leukogram analyses were packed in tubes containing ethylenediaminetetraacetic (EDTA) anticoagulant. Samples for biochemical analyses were conditioned in tubes without anticoagulant. The samples were transported under refrigeration and sent to the Laboratory of Clinical Pathology of the Veterinary Institute of the Federal Rural University of Rio de Janeiro for analysis.

The total plasma protein level was determined by refractometry (Coles, 1984). The level of haemoglobin was assayed by the oxy-haemoglobin method with the samples being centrifuged at $1000 \times g$ for 10 min to determine the optical density using a Klett Summersom ${ }^{\circledR}$ colorimeter and with the value being corrected for the haemoglobin unit (Campbell \& Dein, 1984). Haematocrit was determined by the microhaematocrit method, according to the methodology described by Jain (1993). Red blood cell and total leukocyte counts were performed in a haemocytometer using Natt \& Herrick's solution (Natt \& Herrick, 1951). The blood was diluted $1 / 100$ and $1 / 200$ for the leukocyte and red cell counts, respectively. Leukocytes from the central $1 \mathrm{~mm}^{3}$ quadrant (25 subdivisions of the improved central haemocytometer reticulum) were 
counted and the red cells were counted in this same quadrant in $1 / 5 \mathrm{~mm}^{3}$ (five subdivisions of the improved central haemocytometer reticulum). The correction factors for total leukocyte and erythrocyte counts were the cell counts multiplied by 1000 and 10,000, respectively, taking into account the area and height of the chamber as well as the dilution. For the differential leukocyte count, blood smears were stained with Giemsa to determine relative values and subsequently the absolute values for lymphocytes, heterophils, and monocytes. The mean corpuscular volume (MCV) and mean corpuscular haemoglobin concentration (MCHC) were calculated using the following standardized formulas (Wintrobe, 1933; Haney et al., 1992):

$$
\begin{gathered}
\operatorname{MCV}(\mathrm{fL})=\frac{\text { haematocrit }(\%) \times 10}{\mathrm{RBC}(\mu \mathrm{L}) \times 10^{-6}} \\
\operatorname{MCHC}(\%)=\frac{\text { haemoglobin }(\mathrm{g} / \mathrm{dL}) \times 100}{\text { haematocrit }(\%)}
\end{gathered}
$$

After two hours at ambient temperature, the collected blood without anticoagulant was centrifuged at $400 \times g$ for $5 \mathrm{~min}$ to harvest the serum and then stored at $-20^{\circ} \mathrm{C}$. Analyses of liver and renal function, including the activities of aspartate aminotransferase (AST) (K048, Bioclin, Brazil), alanine aminotransferase (ALT) (K049, Bioclin, Brazil), gamma-glutamyl transferase (GGT) (K080, Bioclin, Brazil), alkaline phosphatase (ALP) (K021, Bioclin, Brazil), creatinine (K067, Bioclin, Brazil), urea (K056, Bioclin, Brazil), and uric acid (K039, Bioclin, Brazil) were performed using a commercial kit and a Bio-2000 automatic spectrophotometer (Bioplus, São Paulo, Brazil), with automatic calibration and high performance reading. The assays were performed using the kinetic method, according to the manufacturer's instructions.

The experiment was conducted in a randomized block design with five treatments and six replicates, with five metal batteries composed of three levels, with each floor representing one block, totalling three blocks per battery and 30 assessments in total.

The results were submitted to analysis of variance, and means were compared using the StudentNewman-Keuls test at 5\% $(P<0.05)$ using SISVAR version 5.3 software (Ferreira, 2011).

\section{Results and Discussion}

No effects of the treatments were observed $(P>0.05)$ for feed intake, weight gain, and feed conversion (Table 2) in the initial phase. The average feed consumption was greater than that suggested for the manual feeding of Cobb 500 broilers (Cobb-Vantress-Brasil, 2008), indicating that any health challenge to which the broilers were subjected with $5 \%$ bedding mixed in the diet did not affect the variables. The performance results in the initial phase are in agreement with those obtained by Kirkpinar et al. (2011) and Alp et al. (2012), who found no difference for feed intake, weight gain and feed conversion at day 21 in broilers

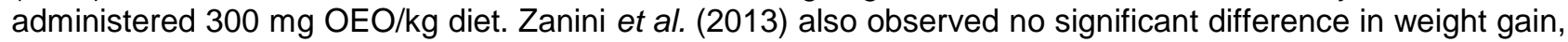
either in the initial phase or in the entire experimentation phase, when broiler feed was supplemented with OEO at $0.5 \mathrm{~g} / \mathrm{kg}$ and $1 \mathrm{~g} / \mathrm{kg}$. Franciosini et al. (2016) reported that when feed was supplemented with a mixture of aqueous extracts of oregano and rosemary $(2 \mathrm{~g} / \mathrm{kg})$, broilers presented a significant improvement in weight gain compared with the control treatment without the extracts.

From day 1 to day 39, chicks treated with the OEO300 diet displayed higher feed intake than those in the negative control group $(P<0.05)$. A similar result was obtained by Tekce \& Gül (2016) when administering OEO (Origanum syriacum) to broilers. Hussein et al. (2015) stressed that even though phytogenic additives are regarded as palatability stimulants, further studies were needed to corroborate this.

Weight gain was not affected $(P>0.05)$ by increasing OEO levels. A similar result was reported by Alp et al. (2012) and Mohiti-Asli \& Ghanaatparast-Rashti (2015), who observed no significant difference in weight gain in broilers supplemented with OEO at $300 \mathrm{mg} / \mathrm{kg}$ and $500 \mathrm{mg} / \mathrm{kg}$ of diet, respectively, compared with the control group.

At the end of the 1- to 39-day period, the lowest feed conversion $(P<0.05)$ was observed in the broilers from the positive control group $(P<0.05)$. Feed conversion in the broilers treated with the three OEO levels did not differ significantly from that of broilers in the negative control group. A similar result was obtained by Rizzo et al. (2010), who observed that broilers treated with antibiotics displayed a lower feed conversion than broilers administered a commercial mixture of oregano and cinnamon essential oils, as well as those of the negative control group. Essential oils can have an important impact on feed conversion and stabilization of microbial populations, and can also increase nutrient absorption (Alagawany et al., 2018). The viability and PEI of the broilers in present research were not significantly affected by the treatments. 
Table 2 Performance of broilers of broilers supplemented with different levels of oregano essential oil or antibiotic

\begin{tabular}{|c|c|c|c|c|c|c|c|}
\hline \multirow[b]{3}{*}{ Performance measures } & \multicolumn{5}{|c|}{ Treatments $^{1}$} & \multirow{3}{*}{$\begin{array}{l}\text { CV } \\
(\%)\end{array}$} & \multirow[b]{3}{*}{$P$-value } \\
\hline & \multirow[b]{2}{*}{$\mathrm{NC}$} & \multirow[b]{2}{*}{ PC } & \multicolumn{3}{|c|}{ OEO (mg/kg) } & & \\
\hline & & & 300 & 600 & 900 & & \\
\hline \multicolumn{8}{|l|}{1 to 21 days old } \\
\hline Feed consumption (g) & 1290 & 1271 & 1286 & 1245 & 1231 & 4.61 & 0.346 \\
\hline Weight gain (g) & 888 & 877 & 913 & 871 & 862 & 4.98 & 0.326 \\
\hline Feed conversion $(\mathrm{g} / \mathrm{g})$ & 1.45 & 1.45 & 1.41 & 1.43 & 1.43 & 3.15 & 0.432 \\
\hline \multicolumn{8}{|l|}{1 to 39 days old } \\
\hline Feed consumption (g) & $4275^{b}$ & $4397^{a b}$ & $4454^{a}$ & $4349^{a b}$ & $4402^{\mathrm{ab}}$ & 2.21 & 0.045 \\
\hline Weight gain (g) & 2579 & 2531 & 2675 & 2620 & 2614 & 3.83 & 0.185 \\
\hline Feed conversion $(\mathrm{g} / \mathrm{g})$ & $1.66^{\mathrm{a}}$ & $1.74^{\mathrm{b}}$ & $1.66^{\mathrm{a}}$ & $1.66^{\mathrm{a}}$ & $1.69^{\mathrm{a}}$ & 2.53 & 0.014 \\
\hline Viability (\%) & 98 & 93 & 100 & 97 & 93 & 6.51 & 0.284 \\
\hline productive efficiency index (\%) & 262 & 257 & 272 & 266 & 266 & 3.57 & 0.150 \\
\hline
\end{tabular}

Row means with different letters differ statistically at $P<0.05$ by the Student-Newman-Keuls (SNK) test

${ }^{1} \mathrm{NC}$ : negative control, PC: positive control (colistin sulfate), OEO: oregano essential oil

Treatment with OEO300 resulted in higher carcass yield $(P<0.05)$ compared with the positive control (Table 3). Peng et al. (2016) reported higher carcass yield in broilers treated with OEO at 300 and $600 \mathrm{mg} / \mathrm{kg}$ diet than in those from the positive control group.

The broilers treated with the OEO900 diet had higher levels $(P<0.05)$ of abdominal fat compared with those from the negative and positive control groups ((Table 3). The broilers treated with OEO300 and OEO600 presented intermediate values of abdominal fat compared with the other treatments.

Deposition of abdominal fat is an unfavourable characteristic since there is a strong and positive correlation between abdominal fat deposition and fat in the carcass, which depreciates the carcass (Gaya et al., 2006). Unlike in this study, Calislar et al. (2009) observed no difference in the relative weight of abdominal fat of broilers administered 300,500 , and $700 \mathrm{ppm}$ of an OEO-based commercial product. In a gene expression analysis of intraepithelial lymphocytes from broiler intestines, Kim et al. (2010) concluded that carvacrol, the main constituent of OEO, modulates lipid metabolism-associated gene expression. Lillehoj et al. (2011) observed that broilers treated with carvacrol displayed altered lipid, linoleic acid, and androgen and oestrogen metabolism. In agreement with these studies, Peng et al. (2016) observed that broilers treated with $600 \mathrm{mg} \mathrm{OEO} / \mathrm{kg}$ had a lower percentage of abdominal fat than broilers treated with $300 \mathrm{mg}$ oregano/kg diet and those in the negative and positive control groups. In contrast, Nieto et al. (2018) did not observe any difference in abdominal fat in broilers treated with essential oils from two oregano species.

The data presented in Table 3 reveal that there was no effect $(P>0.05)$ of the various treatments on the relative weights of the liver, gizzard, heart, bursa, and spleen. These results are in agreement with those of Corduk et al. (2013), who found no difference in the relative weight of the liver and gizzard with administration of $250 \mathrm{mg} \mathrm{OEO} / \mathrm{kg}$. Conversely, Koyama et al. (2014) observed increased bursa weight in broilers from the negative control group and those treated with a mixture of essential oils compared with broilers from the positive control group and those that received less varied essential oil mixtures. The bursa of Fabricius and thymus are the main immune organs in broilers. Maturation of B lymphocytes and production of antibodies occurs in the bursa of Fabricius (Lebien \& Tedder, 2008), which is strategically located at the end of the gastrointestinal tract, allowing contact between cells of the immune system and antigens in the diet (Sharma, 1998). The higher the microbial load, the more active the immune system becomes (Thomke \& Elwinger, 1998). 
Table 3 Carcass, breast, leg, and thigh yield, and relative weights of abdominal fat and edible offal of broilers supplemented with different levels of oregano essential oil or antibiotic

\begin{tabular}{|c|c|c|c|c|c|c|c|}
\hline \multirow[b]{3}{*}{ Trait } & \multicolumn{5}{|c|}{ Treatments $^{1}$} & \multirow{3}{*}{$\begin{array}{l}\text { CV } \\
(\%)\end{array}$} & \multirow[b]{3}{*}{$P$-value } \\
\hline & \multirow[b]{2}{*}{ NC } & \multirow[b]{2}{*}{ PC } & \multicolumn{3}{|c|}{ OEO $(\mathrm{mg} / \mathrm{kg})$} & & \\
\hline & & & 300 & 600 & 900 & & \\
\hline \multicolumn{8}{|l|}{ Yield (\%) } \\
\hline Carcass & $69.27^{\mathrm{ab}}$ & $68.72^{\mathrm{b}}$ & $70.16^{\mathrm{a}}$ & $69.59^{\mathrm{ab}}$ & $70.01^{a b}$ & 1.82 & 0.028 \\
\hline Breast & 37.18 & 38.30 & 38.28 & 38.02 & 38.25 & 4.87 & 0.540 \\
\hline Leg & 15.14 & 14.45 & 14.84 & 15.15 & 14.96 & 5.46 & 0.217 \\
\hline Thigh & 16.98 & 16.78 & 16.50 & 16.64 & 16.19 & 6.00 & 0.383 \\
\hline Wing & $11.18^{\mathrm{ab}}$ & $11.67^{\mathrm{a}}$ & $10.73^{b}$ & $11.35^{\mathrm{ab}}$ & $11.12^{\mathrm{ab}}$ & 5.91 & 0.019 \\
\hline Back & 19.58 & 18.90 & 19.70 & 18.83 & 19.52 & 5.88 & 0.197 \\
\hline \multicolumn{8}{|c|}{ Relative weight (\%) } \\
\hline Abdominal fat & $1.10^{\mathrm{a}}$ & $1.13^{\mathrm{a}}$ & $1.37^{\mathrm{ab}}$ & $1.43^{\mathrm{ab}}$ & $1.63^{b}$ & 32.07 & 0.020 \\
\hline Liver & 2.50 & 2.62 & 2.43 & 2.41 & 2.62 & 15.6 & 0.542 \\
\hline Gizzard & 1.80 & 1.88 & 1.67 & 1.81 & 1.83 & 13.09 & 0.260 \\
\hline Heart & 0.73 & 0.74 & 0.69 & 0.67 & 0.74 & 13.71 & 0.332 \\
\hline Bursa & 0.13 & 0.11 & 0.10 & 0.10 & 0.10 & 26.03 & 0.052 \\
\hline Spleen & 0.18 & 0.19 & 0.18 & 0.17 & 0.16 & 27.82 & 0.637 \\
\hline
\end{tabular}

Means with different letters in the same row differ statistically at $P<0.05$ by the Student-Newman-Keuls (SNK) test

${ }^{1} \mathrm{NC}$ : negative control, PC: positive control (colistin sulfate), OEO: oregano essential oil

All haemogram-related blood parameters were influenced by treatments $(P<0.05)($ Table 4$)$, although the negative control values were within normality for broilers, according to Jain (1993), Cardoso \& Tessari (2003), and Campbell (2007). According to these authors, blood values may be influenced by nutritional status, gender, age, season, trauma, breeding, and environmental stress. Therefore, a negative control that is submitted to the same experimental conditions is essential to evaluate these and other physiological parameters, and is considered more reliable than external reference values.

Table 4 Blood profile for broilers supplemented with different levels of oregano essential oil or antibiotic

\begin{tabular}{|c|c|c|c|c|c|c|c|}
\hline \multirow[b]{3}{*}{ Blood profile measures } & \multicolumn{5}{|c|}{ Treatments $^{1}$} & \multirow{3}{*}{$\begin{array}{l}\text { CV } \\
(\%)\end{array}$} & \multirow[b]{3}{*}{$P$-value } \\
\hline & \multirow[b]{2}{*}{ NC } & \multirow[b]{2}{*}{ PC } & \multicolumn{3}{|c|}{ OEO (mg/kg) } & & \\
\hline & & & 300 & 600 & 900 & & \\
\hline Red blood cells $\left(\mu \mathrm{L} \times 10^{6}\right)$ & $2.28^{\mathrm{a}}$ & $2.27^{\mathrm{a}}$ & $2.43^{\mathrm{b}}$ & $2.68^{\mathrm{bc}}$ & $2.84^{\mathrm{C}}$ & 20.34 & 0.029 \\
\hline Haematocrit (\%) & $32.58^{\mathrm{a}}$ & $24.67^{b}$ & $33.25^{\mathrm{a}}$ & $33.17^{\mathrm{a}}$ & $32.67^{\mathrm{a}}$ & 7.91 & 0.000 \\
\hline Haemoglobin (g/dL) & $7.62^{c}$ & $6.40^{\mathrm{d}}$ & $8.81^{\mathrm{a}}$ & $8.67^{\mathrm{ab}}$ & $8.25^{\mathrm{b}}$ & 7.08 & 0.000 \\
\hline Plasma proteins ( $\mathrm{g} / \mathrm{dL})$ & $4.50^{\mathrm{a}}$ & $3.68^{b}$ & $4.67^{\mathrm{a}}$ & $4.38^{\mathrm{a}}$ & $4.25^{\mathrm{a}}$ & 11.43 & 0.000 \\
\hline Mean corpuscular volume (fL) & $139.51^{\mathrm{a}}$ & $100.30^{c}$ & $125.27^{b}$ & $125.58^{b}$ & $115.77^{b}$ & 11.34 & 0.000 \\
\hline $\begin{array}{l}\text { Mean corpuscular haemoglobin } \\
\text { concentration (\%) }\end{array}$ & $32.63^{\mathrm{a}}$ & $26.10^{\mathrm{b}}$ & $33.09^{\mathrm{a}}$ & $32.98^{\mathrm{a}}$ & $29.20^{\mathrm{a}}$ & 12.12 & 0.000 \\
\hline
\end{tabular}

Means with different letters in the same row differ statistically $(P<0.05)$ by the Student-Newman-Keuls (SNK) test

${ }^{1} \mathrm{NC}$ : negative control, PC: positive control (colistin sulfate), OEO: oregano essential oil

Compared with the negative and positive controls, supplementing the diet with OEO resulted in a marked increase $(P<0.05)$ in red blood cell and haemoglobin levels. The lowest haematocrit was recorded in the positive control $(P<0.05)$, with no difference being observed between treatments. According to Campbell (2007), the normal haematocrit of broilers can vary from $35 \%$ to $55 \%$, representing a broad range and making this parameter too unreliable to correlate with the treatments and be used as isolated data.

The MCV was significantly lower in all the blood samples from broilers treated with OEO at various levels. However, these values were higher than those in broilers treated with the antibiotic colistin sulfate (positive control), and microcytosis was observed in OEO-treated broilers. Broilers from the positive control group had the lowest haematocrit, MCHC, and plasma protein levels $(P<0.05)$, which together could be 
indicative of anaemia and liver dysfunction. These results corroborate those obtained by Tollba et al. (2010), who observed that haematocrit, haemoglobin, and plasma protein levels increased in broilers treated with 1 $\mathrm{g}$ or $2 \mathrm{~g}$ phytogenic additives $/ \mathrm{kg}$ diet, including oregano, compared with control broilers. Levkut et al. (2011) observed that supplementing the diet with OEO resulted in a higher concentration of plasma proteins only at 29 days compared with the control group, while no significant effect was observed in the total period (42 days). In contrast, Traesel et al. (2010) did not observe a significant difference in plasma protein concentrations between broilers treated with a mixture of essential oils (oregano, sage, rosemary, and pepper) at $100 \mathrm{mg} / \mathrm{kg}$ and control groups.

The leukogram results are presented in Table 5. A significant increase in total and differential leukometry was observed in the OEO600 and OEO900 groups compared with the control and OEO300 groups, indicating that supplementing OEO at $300 \mathrm{mg} / \mathrm{kg}$ in feed can be used without significantly changing leukogram values. The differential leukometry indicated that lymphocytes were affected most by the treatment, with a lower value being recorded for the positive control and a higher relative value for the OEO treatments compared with the negative control. The 600 and $900 \mathrm{mg} \mathrm{OEO} / \mathrm{kg}$ levels apparently triggered a response above the normal values reported by Jain (1993), Cardoso \& Tessari (2003), and Campbell (2007), being an expressive non-specific stimulus of immune-mediated response. In contrast, a significant decrease was observed in the total and differential leukometry of the antibiotic-administered group, suggesting either a compromised cell-mediated response owing to depression of leukopoiesis or a decrease in the number of peripheral leukocytes (Schmidt et al., 2007). According to Hong et al. (2012), oregano supplementation increased antibody levels significantly in broiler chickens as a potential stimulator of the immune system. Silva-Vázquez et al. (2018) also observed an increase in leukocyte and lymphocyte numbers when treating broilers with two types of OEO.

Table 5 Leukogram values for broilers supplemented with different levels of oregano essential oil or antibiotic

\begin{tabular}{|c|c|c|c|c|c|c|c|}
\hline \multirow[b]{3}{*}{ Leukogram measures } & \multicolumn{5}{|c|}{ Treatments $^{1}$} & \multirow{3}{*}{$\begin{array}{l}\text { CV } \\
(\%)\end{array}$} & \multirow[b]{3}{*}{$P$-value } \\
\hline & \multirow[b]{2}{*}{ NC } & \multirow[b]{2}{*}{ PC } & \multicolumn{3}{|c|}{ OEO $(\mathrm{mg} / \mathrm{kg})$} & & \\
\hline & & & 300 & 600 & 900 & & \\
\hline Leukocytes $\left(\mu \mathrm{L} \times 10^{3}\right)$ & $31.33^{\mathrm{a}}$ & $25.83^{b}$ & $33.58^{\mathrm{a}}$ & $45.83^{c}$ & $46.92^{c}$ & 16.15 & 0.000 \\
\hline Lymphocytes $\left(\mu \mathrm{L} \times 10^{3}\right)$ & $20.50^{\mathrm{a}}$ & $14.42^{b}$ & $22.12^{\mathrm{c}}$ & $24.16^{d}$ & $26.36^{\mathrm{e}}$ & 15.50 & 0.000 \\
\hline Heterophils $\left(\mu \mathrm{L} \times 10^{3}\right)$ & $8.73^{\mathrm{a}}$ & $8.82^{a}$ & $9.27^{\mathrm{a}}$ & $16.86^{\mathrm{b}}$ & $13.76^{\mathrm{c}}$ & 28.32 & 0.000 \\
\hline Monocytes $\left(\mu \mathrm{L} \times 10^{3}\right)$ & $2.21^{\mathrm{a}}$ & $2.53^{\mathrm{a}}$ & $2.08^{\mathrm{a}}$ & $4.75^{\mathrm{b}}$ & $6.80^{c}$ & 30.94 & 0.000 \\
\hline Heterophil /lymphocyte ratio & $0.43^{\mathrm{a}}$ & $0.62^{b}$ & $0.42^{\mathrm{a}}$ & $0.61^{b}$ & $0.51^{b}$ & 24.06 & 0.000 \\
\hline
\end{tabular}

Means with different letters in the same row differ statistically at $P<0.05$ by the Student-Newman-Keuls (SNK) test

${ }^{1} \mathrm{NC}$ : negative control, PC: positive control (colistin sulfate), OEO: oregano essential oil

Treatment with OEO300 resulted in a heterophil/lymphocyte ratio $(\mathrm{H} / \mathrm{L})$ within the normal reference range (negative control). Long-term stress such as nutritional deficiency can affect the $\mathrm{H} / \mathrm{L}$ ratio, and the magnitude of the changes in leukocyte proportions depends on stress intensity and persistence (Cïrule et al., 2012).

The broilers from the positive control group displayed increased activities of the hepatic enzymes ( $P$ $<0.05)$ AST, GGT, and ALP compared with the other treatments (Table 6). The increases in AST and GGT enzyme activities in the positive control group suggest a significant change in the liver. Some studies have reported that this increase may be because of hepatocyte damage resulting from necrosis or alterations in cell membrane permeability and can be attributed to recent liver dysfunction (Luedde et al., 2014; Yang et al., 2015). Levkut et al. (2011) also observed increased ALP activity in broilers from the control group compared with those treated with OEO in the diet. Increased levels of the enzyme ALP can also represent hepatic involvement, although this enzyme is not sensitive to a diagnosis because of its low activity in hepatobiliary tissue (Campbell, 2007). Reis et al. (2018) found no differences in the AST or ALT activities of broilers supplemented with a phytogenic additive composed of carvacrol, thymol, and cinemaldehyde. Carvacrol, the major constituent of oregano essential oil, exhibits hepatoprotective activity (Alagawany et al., 2015).

The increase in serum urea observed with all the treatments, and that for uric acid in the OEO900 and positive control groups, may be due to the higher coefficient of apparent nitrogen metabolism obtained in the broilers from this group (Dias et al., 2015). Nonetheless, the possibility of impaired renal function and metabolic disorders in broilers treated with the highest OEO levels cannot be ruled out. Increases in the 
serum levels of these metabolites occur when $30 \%$ or less of the kidney is functional, or because of pre- and post-renal causes (Fudge \& Joseph, 2000; Kaneko, 2008).

Table 6 Serum biochemistry values for broilers supplemented with different levels of oregano essential oil or antibiotic

\begin{tabular}{|c|c|c|c|c|c|c|c|}
\hline \multirow[b]{3}{*}{ Enzymes/metabolites } & \multirow[b]{3}{*}{ NC } & \multirow[b]{3}{*}{ PC } & \multicolumn{3}{|c|}{ Treatments $^{1}$} & \multirow{3}{*}{$\begin{array}{l}\text { CV } \\
(\%)\end{array}$} & \multirow[b]{3}{*}{$P$-value } \\
\hline & & & \multicolumn{3}{|c|}{ OEO (mg/kg) } & & \\
\hline & & & 300 & 600 & 900 & & \\
\hline Aspartate aminotransferase (IU/L) & $276.43^{\mathrm{a}}$ & $487.91^{\mathrm{b}}$ & $276.98^{\mathrm{a}}$ & $327.65^{a}$ & $329.61^{a}$ & 32.16 & 0.000 \\
\hline Alanine aminotransferase (IU/L) & $28.81^{\mathrm{a}}$ & $36.28^{\mathrm{b}}$ & $28.67^{\mathrm{a}}$ & $32.59^{c}$ & $32.59^{c}$ & 20.82 & 0.038 \\
\hline Gamma glutamyltransferase (IU/L) & $10.25^{\mathrm{a}}$ & $19.09^{b}$ & $7.61^{\mathrm{a}}$ & $11.67^{\mathrm{a}}$ & $11.67^{\mathrm{a}}$ & 35.32 & 0.000 \\
\hline alkaline phosphatase (IU/L) & $1733^{\mathrm{a}}$ & $2278^{b}$ & $1781^{\mathrm{a}}$ & $1815^{a}$ & $1815^{\mathrm{a}}$ & 20.63 & 0.007 \\
\hline Urea $(\mathrm{mg} / \mathrm{dL})$ & $0.47^{\mathrm{a}}$ & $0.57^{\mathrm{b}}$ & $0.45^{\mathrm{a}}$ & $0.55^{\mathrm{b}}$ & $0.67^{\mathrm{b}}$ & 21.22 & 0.000 \\
\hline Creatinine $(\mathrm{mg} / \mathrm{dL})$ & $5.50^{\mathrm{ab}}$ & $4.33^{b}$ & $4.58^{\mathrm{b}}$ & $4.33^{\mathrm{b}}$ & $6.75^{\mathrm{a}}$ & 30.97 & 0.001 \\
\hline Uric acid (mg/dL) & $15.13^{\mathrm{a}}$ & 22.33 & $15.14^{\mathrm{a}}$ & $17.90^{\mathrm{a}}$ & $22.80^{\mathrm{b}}$ & 28.91 & 0.000 \\
\hline
\end{tabular}

Means with different letters in the same row differ statistically $(P<0.05)$ by the Student-Newman-Keuls (SNK) test

${ }^{1} \mathrm{NC}$ : negative control, PC: positive control (colistin sulfate), OEO: oregano essential oil

\section{Conclusions}

Broilers treated with OEO displayed a stimulated immune system, while broilers treated with $300 \mathrm{mg}$ OEO $/ \mathrm{kg}$ of diet presented values within the reference range. The use of OEO in the diets did not harm the performance and carcass characteristics of broilers. At a concentration of $300 \mathrm{mg} / \mathrm{kg}$, OEO can be used in broiler diets as a phytogenic additive, especially in diets without antimicrobial performance enhancers.

\section{Acknowledgements}

To CAPES (Coordenação do Aperfeiçoamento do Pessoal do Ensino Superior) for help in carrying out this work, and Givaudan do Brasil for providing the microencapsulated oregano essential oil.

\section{Authors' Contributions}

GE, AVCG and CARL designed the study, collected and analysed the data, drafted and revised the manuscript. LSLA, BST and FD collected the data. GE, AVCG, FD, CARL and VSC analysed the data and revised the manuscript.

\section{Conflict of Interest Declaration}

The authors declare that there was no conflict of interest.

\section{References}

Alagawany, M., El-Hack, M.E.A., Farag, M.R., Tiwari, R. \& Dhama, K., 2015. Biological effects and modes of action of carvacrol in animal and poultry production and health - A review. Adv. Anim. Vet. Sci. 3 (2), 73-84. Doi: 10.14737/journal.aavs/2015/3.2s.73.84

Alagawany, M., Abdel-Hack, M.E., Farag, M.R., Shaheen, H.M., Abdel-Latif, M.A., Noreldin, A.E. \& Patra, A.K., 2018. The usefulness of oregano and its derivatives in poultry nutrition. Worlds Poult. Sci. J. 74, 1-11. Doi: https://doi.org/10.1017/S0043933918000454

Alp, M., Midilli, M., Kocabağl, N., Yilmaz, H., Turan, N., Gargili, A. \& Acar, N., 2012. The effects of dietary oregano essential oil on live performance, carcass yield, serum immunoglobulin G level, and oocyst count in broilers. J. Appl. Poult. Res. 21, 630-636. Doi: https://doi.org/10.3382/japr.2012-00551

Bedoya-serna, C.M., Dacanal, G.C., Fernandes, A.M. \& Pinho, S.C., 2018. Antifungal activity of nanoemulsions encapsulating oregano (Origanum vulgare) essential oil: In vitro study and application in Minas Padrão cheese. Braz. J. Microbiol. 49 (4), 929-935. Doi: http://dx.doi.org/10.1016/j.bjm.2018.05.004

Burt, S., 2004. Essential oils: Their antibacterial properties and potential applications in foods - a review. Int. J. Food Microbiol. 94 (3), 223-253. Doi: https://doi.org/10.1016/j.ijfoodmicro.2004.03.022

Calislar, S., Gemci, I. \& Kamalak, A., 2009. Effects of Orego-Stim ${ }^{\circledR}$ on broiler chick performance and some blood $\begin{array}{lllllll}\text { parameters. } & \text { J. Anim. } & \text { Vet. } & \text { Adv. } & \text { (12), } & \text { 2617-2620. } & \text { Doi: }\end{array}$ http://medwelljournals.com/abstract/?doi=javaa.2009.2617.2620

Campbell, T.W., 2007. Hematologia De Mamíferos Não Domésticos, Aves, Répteis, Peixes E Anfíbios Comuns. In: M. A. Thrall. Hematologia E Bioquímica Clínica Veterinária. 1st edition. Editora Roca. São Paulo. 215-247. (In Portuguese).

Campbell, T.W. \& Dein, F.J., 1984. Avian hematology. The basics. Vet. Clin. North Am. Small Anim. Pract. 14 (2), $223-$ 248. Doi: 10.1016/S0195-5616(84)50031-X 
Cardoso, A.L.S.P. \& Tessari, E.N.C., 2003. Estudo dos parâmetros hematológicos em frangos de corte. Arq. Inst. Biol. 70, 419-424. Doi: http://www.biologico.sp.gov.br/uploads/docs/arq/V70_4/cardoso.pdf (In Portuguese, English abstract).

Cïrule, D., Krama, T., Vrublevska, J., Rantala, M.J. \& Krams, I., 2012. A rapid effect of handling on counts of white blood cells in a wintering passerine bird: A more practical measure of stress? J. Ornithol. 153, 161-166. Doi: 10.1007/s10336-011-0719-9

Cobb-Vantress-Brasil, 2008. Manual de frangos de corte Cobb 500: suplemento de crescimento e nutrição para frangos de corte. Cobb-Vantress Brasil. Guapiaçu, São Paulo, Brasil. 8. (In Portuguese)

Coles, E.H., 1984. Patologia Clínica Veterinária. 3rd edition. Editora Manole. São Paulo, Brasil. 566. (In Portuguese)

Corduk, M., Sarica, S. \& Yarim, G.F., 2013. Effects of oregano or red pepper essential oil supplementation to diets for broiler chicks with delayed feeding after hatching. 1. Performance and microbial population. J. Appl. Poult. Res. 22, 738-749. Doi: https://academic.oup.com/japr/article/22/4/738/762244

Dias, G.E.A., Carvalho, B.O., Gomes, A.V.C., Medeiros, P.T.C., Sousa, F.D.R., Souza, M.M.S. \& Lima, C.A.R., 2015. Óleo essencial de orégano (Origanum vulgare L.) na dieta de frangos de corte como equilibrador da microbiota intestinal. Rev. Bras. Med. Vet. 37, 108-114. Doi: http://rbmv.org/index.php/BJVM/article/view/380 (In Portuguese, English abstract).

Ferreira, D.F., 2011. Sisvar: A computer statistical analysis system. Ciênc. Agrotec. 35, 1039-1042.

Franciosini, M.P., Casagrande-Proietti, P., Forte, C., Beghelli, D., Acuti, G., ..., Trabalza-Marinucci, M., 2016. Effects of oregano (Origanum vulgare L.) and rosemary (Rosmarinus officinalis L.) aqueous extracts on broiler performance, immune function and intestinal microbial population. J. Appl. Anim. Res. 44, 474-479. Doi: https://doi.org/10.1080/09712119.2015.1091322

Fudge, A.M. \& Joseph, V., 2000. Avian complete blood count. In: A. M. Fudge (ed). Laboratory medicine: Avian and exotic pets. Saunders, Philadelphia. 19-27.

Gandra, E.A., Nogueira, M.B., Chim, J.F., Machado, M.R.G., Rodrigues, R.S., Zambiazi, R.C., Voloski, F.L.S., Schneid, I. \& Freitas, P.F., 2013. Potencial antimicrobiano y antioxidante de extractos vegetales de romero, hinojo, $\begin{array}{lllllll}\text { estragón y orégano. Rev. Cienc. Tecnol. } 15 & \text { (20), 24-29. Doi: }\end{array}$ https://www.fceqyn.unam.edu.ar/recyt//index.php/recyt/article/download/397/314/ (In Portuguese, English abstract).

Gaya, L.G., Mourão, G.B. \& Ferraz, J.B.S., 2006. Aspectos genético-quantitativos de características de desempenho, carcaça e composição corporal em frangos. Cienc. Rural 36 (2), 709-716. Doi: http://dx.doi.org/10.1590/S010384782006000200058 (In Portuguese, English abstract).

Haney, D.C., Hursh, D.A., Mix, M.C. \& Winton, J.R., 1992. Physiological and haemotological changes in chum salmon artificially infected with erythrocytes necrosis virus. J. Aquat. Anim. Health 4, 48-57. Doi: https://doi.org/10.1577/1548-8667(1992)004\%3C0048:PAHCIC\%3E2.3.CO;2

He, X., Hao, D., Liu, C., Zhang, X., Xu, D., Xu, X., Wang, J. \& Wu, R., 2017. Effect of supplemental oregano essential oils in diets on production performance and relatively intestinal parameters of laying hens. Am. J. Mol. Biol. 7, 7385. Doi: 10.4236/ajmb.2017.71006.

Hong, J.C., Steiner, T., Aufy, A. \& Lien, T.F., 2012. Effects of supplemental essential oil on growth performance, lipid metabolites and immunity, intestinal characteristics, microbiota and carcass traits in broilers. Livest. Sci. 144, 253262. Doi: 10.1016/j.livsci.2011.12.008

Hussein, S.H.M., Laz, E.S., Salem, H.H. \& Allah, T.I.H., 2015. Phytogenics as animal feed additive. Egypt. J. Chem. Environ. Health 1, 421-434. Doi: http://cehea.org/wp-content/uploads/2016/08/30.pdf

Jacela, J.Y., Frobose, H.L., Derouchey, J.M., Tokach, M.D., Dritz, S.S., Goodband, R.D. \& Nelssen, J.L., 2010. Amino acid digestibility and energy concentration of high-protein corn dried distillers grains and high-protein sorghum dried distillers grains with solubles for swine. J. Anim. Sci. 88, 3617-3623. Doi: 10.2527/jas.2010-3098

Jain, N.C., 1993. Essentials of veterinary hematology. Lea \& Febiger, Philadelphia. 417.

Kaneko, J.J., 2008. Appendixes. In: J. J. Kaneko. Clinical biochemistry of domestic animals. 6th edition. Academic Press, San Diego. 877-901.

Kim, D.K., Lillehoj, H.S., Lee, S.H. \& Jang, S.I.; Bravo, D., 2010. High-throughput gene expression analysis of intestinal intraepithelial lymphocytes after oral feeding of carvacrol, cinnamaldehyde, or Capsicum oleoresin. Poult. Sci. 89, 68-81. Doi: 10.3382/ps.2009-00275

Kirkpinar, F., Ünlü, H.B. \& Özdemir, G., 2011. Effects of oregano and garlic essential oils on performance, carcass, organ and blood characteristics and intestinal microflora of broilers. Livest. Sci. 137, 219-225. Doi: 10.1080/00071668.2013.879980

Koyama, N.T.G., Rosa, A.P., Padilha, T.S., Boemo, L.S., Scher, A., Melo, A.M.S. \& Fernandes, M.O., 2014. Desempenho e rendimento de carcaça de frangos de corte alimentados com mistura de aditivos fitogênicos na dieta. Pesq. Agropec. Bras. 49 (3), 225-231. Doi: http://dx.doi.org/10.1590/S0100-204X2014000300009 (In Portuguese, English abstract).

Lebien, T.W. \& Tedder, T.F., 2008. B lymphocytes: How they develop and function. Blood 112 (5), 1570-1579. Doi: https://doi.org/10.1182/blood-2008-02-078071

Levkut, M., Marcin, A., Revajová, V., Lenhardt, L., Danielovi, I., Hecl, J., Blanár, J., Levkutová, M. \& Pistl, J., 2011. Influence of oregano extract on the intestine, some plasma parameters and growth performance in chickens. Acta Vet. (Beogr.) 61 (2-3), 215-225. Doi: 10.2298/AVB1103215L

Lillehoj, H.S., Kim, D.K., Bravo, D.M. \& Lee, S.H., 2011. Effects of dietary plant-derived phytonutrients on the genomewide profiles and coccidiosis resistance in the broiler chickens. BMC Proc. 5 (suppl 4), 34-42. Doi: 10.1186/17536561-5-S4-S34 
Luedde, T., Kaplowitz, N. \& Schwabe, F., 2014. Cell death and cell death responses in liver disease: mechanisms and clinical relevance. Gastroenterology 147, 765-783. Doi: 10.1053/j.gastro.2014.07.018

Madhupriya, V., Shamsudeen, P., Manohar, G.R., Senthilkumar, S., Soundarapandiyan, V. \& Moorthy, M., 2018. Phyto feed additives in poultry nutrition - a review. Int. J. Sci. Environ. Technol. 7 (3), 815-822. Doi: http://www.ijset.net/journal/2109.pdf

Martins, E.R., Castro, D.M., Castellani, D.C. \& Dias, J.E., 2003. Plantas medicinais. UFV, Imprensa Universitária. Viçosa, MG, Brasil. 220.

Mathlouthi, N., Bouzaienne, T., Oueslati, I., Recoquillay, F., Hamdi, M., Urdaci, M. \& Bergaoui, R., 2012. Use of rosemary, oregano, and a commercial blend of essential oils in broiler chickens: In vitro antimicrobial activities and effects on growth performance. J. Anim. Sci. 90, 813-823. Doi: 10.2527/jas.2010-3646

Mohitl-Asli, M. \& Ghanaatparast-Rashtl, M., 2015. Dietary oregano essential oil alleviates experimentally induced coccidiosis in broilers. Prev. Vet. Med. 120,195-202. Doi: 10.1016/j.prevetmed.2015.03.014

Mohiti-Asli, M. \& Ghanaatparast-Rashti, M., 2017. Comparison of the effect of two phytogenic compounds on growth performance and immune response of broilers. J. Appl. Anim. Res. 45, 603-608. Doi: https://doi.org/10.1080/09712119.2016.1243119

Natt, M.P. \& Herrick, C.A., 1951. A new blood diluent for counting the erythrocytes and leucocytes of the chicken. Poult. Sci. 31, 735-738. Doi: https://doi.org/10.3382/ps.0310735

Nieto, C.A., Ortiz, R.E. \& Tellez, G.A., 2018. Effect of two chemotypes of oregano essential oil on broiler performance, nutrient balance, and lipid peroxidation of breast meat during storage. Ciênc. Anim. Bras. 19, 1-15. Doi: http://dx.doi.org/10.1590/1809-6891v19e-47819

Peng, Q.Y., Li, J.D., Li, Z., Duan, Z.Y. \& Wu, Y.P., 2016. Effects of dietary supplementation with oregano essential oil on growth performance, carcass traits and jejunal morphology in broiler chickens. Anim. Feed Sci. Technol. 214,148153. Doi: https://dx.doi.org/10.1016/j.anifeedsci.2016.02.010

Reis, J.H., Gebert, R.R., Barreta, M., Baldissera, M.D., Santos, I.D., ..., Silva, A.S., 2018. Effects of phytogenic feed additive based on thymol, carvacrol and cinnamic aldehyde on body weight, blood parameters and environmental bacteria in broilers chickens. Microb. Pathog. 125,168-176. Doi: 10.1016/j.micpath.2018.09.015

Ri, C.S., Jiang, X.R., Kim, M.H., Wang, J., Zhang, H.J., Wu, S.G., Bontempo, V. \& Qi, G.H., 2017. Effects of dietary oregano powder supplementation on the growth performance, antioxidant status and meat quality of broiler chicks. Ital. J. Anim. Sci. 16 (2), 246-252. Doi: https://doi.org/10.1080/1828051X.2016.1274243

Rizzo, P.V., Menten, J.F.M., Racanicci, A.M.C., Traldi, A.B., Silva, C.S. \& Pereira, P.W.Z., 2010. Extratos vegetais em dietas para frangos de corte. R. Bras. Zootec. 39 (4), 801-807. Doi: 10.1590/S1516-35982010000400015

Rostagno, H.S., Albino, L.F.T., Donzele J.L., Gomes, P.C., Oliveira, R.F., Lopes, D.C., Ferreira, A.S. \& Barreto, S.L.T., 2005. Tabelas brasileiras para aves e suínos: composição de alimentos e exigências nutricionais. 2nd edition. UFV, Departamento de Zootecnia. Viçosa, MG, Brasil. 186.

Schmidt, E.M.S., Locatelli-Dittrich, R., Santin, E. \& Paulillo, A.C., 2007. Patologia clínica em aves de produção - Uma ferramenta para monitorar a sanidade avícola - Revisão. Arch. Vet. Sci. 12 (3), 9-20. Doi: http://dx.doi.org/10.5380/avs.v12i3.10906 (In Portuguese, English abstract).

Sharma, J.M., 1998. Avian Immunology. In: P. P. Pastoret, P. Griebel, H. Bazin \& A. Govaerts. Handbook of vertebrate immunology. Academic Press Ltd., London, UK. 73-136.

Silva-Vázquez, R., Duran-Meléndez, L.A., Hernández-Martínez, C.A., Gutiérrez-Soto, J.G., Hume, M.E. \& MéndezZamora, G., 2018. Effects of two sources of Mexican oregano oil on performance, blood profile, carcass variables, and meat of broilers. R. Bras. Zootec. 47, 1-10. Doi: http://dx.doi.org/10.1590/rbz4720170198

Tekce, E. \& Gül, M., 2016. Effects of Origanum syriacum essential oil added in different levels to the diet of broilers under heat stress on performance and intestinal histology. Europ. Poult. Sci. 80, 1-11. Doi: 10.1399/eps.2016.157

Thomke, S. \& Elwinger, K., 1998. Growth promotants in feeding pigs and poultry. II Mode of action of antibiotic growth promotants. Ann. Zootech. 47, 153-167. Doi: https://hal.archives-ouvertes.fr/hal-00889729/document

Tollba, A.A.H., Shabaan, S.A.M. \& Abdel-Mageed, M.A.A., 2010. Effects of using aromatic herbal extract and blended with organic acids on productive and physiological performance of poultry. Egypt. Poult. Sci. 30, 229-248. Doi: https://www.cabdirect.org/cabdirect/abstract/20113051701

Traesel, C.K., Wolkmer, P., Schmidt, C., Silva, C.B., Paim, F.C., Santurio, J.M. \& Lopes, S.T.A., 2010. Serum biochemical profile and performance of broiler chickens fed diets containing essential oils and pepper. Comp. Clin. Path. 20 (5), 453-460. Doi: 10.1007/s00580-010-1018-1

Wintrobe, M.M., 1933. Variations in the size and hemoglobin content of eritrocytes in the blood of various vertebrates. Folia Haematol. (Leipzig). 51, 31.

Yang, M., Antoine, D.J., Weemhoff, J.L., Jenkins, R.E., Farhood, A., Park, B.K. \& Jaeschke, H., 2015. Biomarkers distinguish apoptotic and necrotic cell death during hepatic ischemia-reperfusion injury in mice. Liver. Transpl. 20 (11), 1372-1382. Doi: 10.1002/lt.23958

Zanini, S.F., Sousa, D.R., Rodrigues, M.R.A., Silva, M.A., Zanini, M.S. \& Colnago, G.L., 2013. Oregano essential oil as antimicrobial agent in broilers diet. Arch. Vet. Sci. 18 (4), 1-7. Doi: 10.5380/avs.v18i4.30331 